\title{
PERSPEKTYWA NOWYCH PRZEPISÓW TECHNICZNO-BUDOWLANYCH DOTYCZĄCYCH BUDYNKÓW W ŚWIETLE WADLIWOŚCI DOTYCHCZASOWEJ REGULACJI
}

\author{
Kamil Kułaga ${ }^{\bowtie}$ \\ Instytut Inżynierii Lądowej, Szkoła Główna Gospodarstwa Wiejskiego w Warszawie
}

\begin{abstract}
STRESZCZENIE
W artykule przeanalizowano okoliczności zaistnienia obowiązku wydania nowych przepisów techniczno-budowlanych oraz na przykładzie aktualnego rozporządzenia w sprawie warunków technicznych, jakim powinny odpowiadać budynki i ich usytuowanie, przedstawiono wybrane wady tej regulacji i niektóre zadania stojące przed prawodawcą mającym zaprojektować nowe rozporządzenie. Uzasadniono ogólną negatywną ocenę jakości dotychczasowych przepisów, na którą wpływ mają przede wszystkim uchybienia o charakterze legislacyjnym.
\end{abstract}

Słowa kluczowe: warunki techniczne, budynki, nowe przepisy, technika prawodawcza

\section{WSTĘP}

Przepisy techniczno-budowlane, zwłaszcza te określające warunki techniczne, jakim powinny odpowiadać obiekty budowlane i ich usytuowanie, ustalają oczekiwany przez prawodawcę minimalny standard techniczny podstawowych elementów obiektów budowlanych objętych tymi przepisami. Wpływ obowiązujących regulacji na właściwości użytkowe obiektów budowlanych oceniany jest przede wszystkim pod kątem proporcjonalności oraz adekwatności technicznej narzucanych wymagań. Jednak istotnym kryterium oceny może być także sam sposób formułowania przepisów. Od ich jakości legislacyjnej, postrzeganej w kategoriach komunikatywności i precyzyjności, zależy bowiem skuteczność poprawnego odczytywania przez adresatów przepisów treści norm prawnych w nich zawartych. $Z$ aktualnych przepisów ustawowych wynika, że należy spodziewać się wydania nowych przepisów techniczno-budowlanych.

\section{CZASOWE ZACHOWANIE W MOCY AKTUALNYCH PRZEPISÓW}

22 sierpnia 2018 r. weszła w życie ustawa z dnia 5 lipca 2018 r. o ułatwieniach w przygotowaniu i realizacji inwestycji mieszkaniowych oraz inwestycji towarzyszących (zwana dalej specustawą mieszkaniową), za pośrednictwem której wprowadzono m.in. zmianę w art. 5 ust. 1 ustawy z dnia 7 lipca 1994 r. - Prawo budowlane (zwanej dalej ustawą Prawo budowlane). Zmiana polegała na korekcie brzmienia pkt 4 tego przepisu oraz dodaniu pkt 4a, w którym sformułowane zostało wymaganie, aby w budynkach mieszkalnych wielorodzinnych zapewnione były lokale mieszkalne dostępne dla osób niepełnosprawnych. Do art. 5 ust. 1 ustawy Prawo budowlane odsyła m.in. art. 7 tej ustawy, a więc przepis stanowiący upoważnienie do wydawania przepisów techniczno-budowlanych. Artykuł 5 ust. 1 jest zatem przepisem, w którym zawarte są wytyczne dotyczące treści rozporządzeń ustanawiają- 
cych przepisy techniczno-budowlane. $\mathrm{Z}$ tego powodu jego zmiana oznacza zmianę treści upoważnienia, a to $\mathrm{z}$ kolei oznacza, że z dniem wejścia w życie przepisu ustawy zmieniającego treść przepisu upoważniającego automatycznie tracą moc obowiązującą rozporządzenia wykonawcze wydane na podstawie takiego upoważnienia. Automatyzm ten wynika z celu wydawania rozporządzeń, jakim jest wykonywanie ustaw (art. 92 ust. 1 Konstytucji Rzeczypospolitej Polskiej z dnia 2 kwietnia 1997 r., zwanej dalej Konstytucją RP). Kiedy ustawa - w zakresie treści upoważnienia, tj. obrębu spraw wydzielonych dla prawodawcy wykonawczego i wytycznych dotyczących uregulowania tych spraw - zostaje zmieniona, to uznaje się (niezależnie od skali zmian), że dotychczasowe rozporządzenia nie wykonują zmienionej ustawy (czyli tej nowo obowiązującej), lecz ustawę dotychczasową (już nieobowiązującą, a zatem de facto inną). Chcąc czasowo zachować w mocy dotychczasowe akty wykonawcze - pod warunkiem, że nie są one niezgodne ze zmienioną ustawą - ustawodawca może sformułować w ustawie odpowiedni przepis przejściowy ( $\$ 33$ ust. 1 pkt 2 załącznika do rozporządzenia Prezesa Rady Ministrów z dnia 20 czerwca 2002 r. w sprawie „Zasad techniki prawodawczej”). $\mathrm{W}$ specustawie mieszkaniowej taki przepis został zawarty - jej art. 58 stanowił, że wszystkie dotychczasowe rozporzadzenia wydane na podstawie art. 7 ust. 2 i 3 ustawy Prawo budowlane (rozporządzeń tych jest aktualnie około 20) zachowuja moc obowiązującą nie dłużej niż przez 36 miesięcy (czyli maksymalnie do 22 sierpnia 2021 r.). Oprócz przepisów techniczno-budowlanych przepis ten zachował czasowo w mocy także przepisy wydane na podstawie art. 34 ust. 6 ustawy Prawo budowlane, tj. rozporzadzenie Ministra Transportu, Budownictwa i Gospodarki Morskiej z dnia 25 kwietnia 2012 r. w sprawie szczegółowego zakresu i formy projektu budowlanego oraz rozporządzenie Ministra Transportu, Budownictwa i Gospodarki Morskiej z dnia 25 kwietnia $2012 \mathrm{r}$. w sprawie ustalania geotechnicznych warunków posadawiania obiektów budowlanych. W przypadku tych dwóch rozporządzeń przyczyną utraty mocy obowiązującej miała być zmiana, jaką specustawa mieszkaniowa wprowadziła w art. 34 ust. 3 ustawy Prawo budowlane.

Rok później - ustawą z dnia 19 lipca 2019 r. o zapewnianiu dostępności osobom ze szczególnymi po- trzebami (zwaną dalej ustawą o dostępności) - dokonano zmiany art. 58 specustawy mieszkaniowej w taki sposób, że dotychczasowe przepisy wykonawcze wydane na podstawie art. 7 ust. 2 i 3 oraz art. 34 ust. 6 ustawy Prawo budowlane zachowano w mocy nie na maksymalnie 36 miesięcy, ale bez określania terminu (art. 54 ustawy o dostępności). Równocześnie jednak ustawą o dostępności (art. 44) dokonano zmian bezpośrednio w art. 7 oraz w art. 34 ust. 2 ustawy Prawo budowlane, w konsekwencji czego sformułowano kolejny przepis przejściowy (art. 66 ustawy o dostępności) zachowujący w mocy - nie dłużej niż przez 36 miesięcy (czyli tym razem maksymalnie do 20 września 2022 r.) - dotychczasowe rozporządzenia wydane na podstawie art. 7 ust. 2 i 3 ustawy Prawo budowlane oraz dotychczasowe rozporzadzenie wydane na podstawie jej art. 34 ust. 6 pkt 1 . W tym ostatnim przypadku uznano więc, że ingerencja $\mathrm{w}$ art. 34 ust. 2 ustawy Prawo budowlane prowadzi do utraty mocy obowiązującej jedynie rozporządzenia określającego szczegółowy zakres i formę projektu budowlanego (w specustawie mieszkaniowej niefortunnie przyjęto, że tamtejsza ingerencja w art. 34 ust. 3 ustawy Prawo budowlane prowadzi do utraty mocy także rozporządzenia wydanego na podstawie art. 34 ust. 6 pkt 2, tj. aktu określającego szczegółowe zasady ustalania geotechnicznych warunków posadawiania obiektów budowlanych). $Z$ dalszych rozważań niniejszego artykułu można jednak wykluczyć rozporządzenie z 2012 r. dotyczące projektu budowlanego, ponieważ utraciło ono moc obowiązującą 19 września 2020 r., tj. w dniu wejścia $\mathrm{w}$ życie innej ustawy zmieniającej przepisy dotyczące projektu budowlanego (ustawy $\mathrm{z}$ dnia 13 lutego 2020 r. o zmianie ustawy - Prawo budowlane oraz niektórych innych ustaw).

Zawężając przedmiot dalszego zainteresowania do przepisów techniczno-budowlanych, należy podsumować, że prawodawcy wykonawczy (właściwi ministrowie) mają obowiązek wydania nowych rozporządzeń ustanawiających te przepisy do 2022 r.; muszą one wejść w życie nie później niż 21 września 2022 r. (ich wydanie i ogłoszenie w Dzienniku Ustaw musi rzecz jasna nastąpić $\mathrm{z}$ odpowiednim wyprzedzeniem). Należy tutaj zastrzec, że dopuszczalne jest niewydanie jedynie rozporządzeń określających warunki techniczne użytkowania obiektów budowlanych - upoważnie- 
nie do ich wydania (art. 7 ust. 3 ustawy Prawo budowlane) ma bowiem charakter fakultatywny (ministrowie „mogą określić”), a więc brak nowych rozporządzeń będzie oznaczać utratę z dniem 20 września 2022 r. mocy obowiązującej dotychczasowych przepisów.

Niestety sumienność prawodawców wykonawczych $\mathrm{w}$ zakresie terminowości wywiązywania się z obowiązków ustanawiania przepisów techniczno-budowlanych jest dość mała. Niech potwierdzeniem tej oceny będzie to, że choć wspomniana na początku specustawa mieszkaniowa z 2018 r. funkcjonuje w świadomości branży budowlanej jako źródło obowiązku wydania nowych przepisów techniczno-budowlanych, faktycznie obowiązek ten oczekuje na realizacje co najmniej ${ }^{1}$ od $2015 \mathrm{r}$. Wtedy bowiem przyjęto ustawę $\mathrm{z}$ dnia 25 czerwca 2015 r. o zmianie ustawy o wyrobach budowlanych, ustawy - Prawo budowlane oraz ustawy o zmianie ustawy o wyrobach budowlanych oraz ustawy o systemie oceny zgodności (zwaną dalej nowelizacją z 2015 r.), która zmieniwszy art. 5 ust. 1 ustawy Prawo budowlane, dotychczasowe przepisy techniczno-budowlane utrzymała w mocy - inaczej niż ustawa o dostępności i początkowo specustawa mieszkaniowa - bez określenia maksymalnego terminu na wydanie nowych przepisów (art. 8 ust. 2 nowelizacji z 2015 r.). Formalnie bezterminowe pozostawienie w mocy dotychczasowych aktów wykonawczych w praktyce oznacza jednak, że obowiązek wydania nowych przepisów powinien być zrealizowany bez zbędnej zwłoki (wyrok TK w sprawie o sygn. P 22/05). Tymczasem od wejścia w życie nowelizacji z 2015 r., tj. od 1 stycznia 2016 r., nie wydano ani jednego nowego rozporządzenia ustanawiającego rzeczone przepisy.

\section{ANALIZA WADLIWOŚCI WYBRANYCH UNORMOWAŃ}

Niezależnie od przewidywań w sprawie możliwych terminów wydania nowych przepisów techniczno-budowlanych, czas obowiązywania większości $\mathrm{z}$ dotychczasowych był wystarczający, aby w zainte- resowanych segmentach branży budowlanej utrwaliły się pewne ogólne oceny poszczególnych regulacji. W odniesieniu na przykład do budynków dominuje stanowcze przekonanie o wadliwości przepisów dotyczących tego najpowszechniej realizowanego rodzaju obiektów budowlanych. W dalszej części artykułu przedstawiono kilka argumentów potwierdzających tę ocenę. Analiza treści rozporządzenia Ministra Infrastruktury z dnia 12 kwietnia 2002 r. w sprawie warunków technicznych, jakim powinny odpowiadać budynki i ich usytuowanie (zwanego dalej rozporządzeniem WT z 2002 r.), przeprowadzona zwłaszcza pod kątem ramowej zgodności z niektórymi przepisami aktów normatywnych wyższego rzędu oraz zbieżności $\mathrm{z}$ podstawowymi standardami formułowania przepisów prawa, pozwoliła zidentyfikować istotne wady obowiązującej regulacji oraz na ich tle nakreślić oczekiwane kierunki przyszłych unormowań.

\section{Podstawowe wymagania}

Zmiana art. 5 ust. 1 ustawy Prawo budowlane dokonana nowelizacją z 2015 r. polegała głównie na tym, że w odniesieniu do treści podstawowych wymagań dotyczących obiektów budowlanych zastosowano odesłanie do załącznika I rozporządzenia Parlamentu Europejskiego i Rady (UE) 305/2011 z dnia 9 marca 2011 r. ustanawiającego zharmonizowane warunki wprowadzania do obrotu wyrobów budowlanych i uchylającego dyrektywę Rady 89/106/EWG (zwanego dalej unijnym rozporządzeniem 305/2011). W konsekwencji tego zbędne stało się przytaczanie w przepisach techniczno-budowlanych rozwinięcia (zawartego w rzeczonym załączniku) tych wymagań. Uwzględnienie w rozporządzeniu WT z 2002 r. treści wymagań podstawowych odniesionych do budynków (m.in. § 203, § 207, § 291, § 309, § 323) było przeniesieniem tych wymagań z dyrektywy Rady 89/106/ /EWG z dnia 21 grudnia 1988 r. w sprawie zbliżenia przepisów ustawowych, wykonawczych i administracyjnych państw członkowskich odnoszących się do wyrobów budowlanych (zwanej dalej dyrektywą

\footnotetext{
${ }^{1}$ Niewykluczone, że pogłębiona analiza wcześniejszych zmian ustawy Prawo budowlane, w tym zwłaszcza analiza uwzględniająca możliwość wystąpienia tzw. uchylenia pośredniego, może wykazać, że istnieją podstawy do uznania, że wybrane przepisy techniczno-budowlane w ogóle już nie obowiązują. Badanie tego zagadnienia nie jest jednak przedmiotem niniejszego artykułu.
} 
Kułaga, K. (2020). Perspektywa nowych przepisów techniczno-budowlanych dotyczących budynków w świetle wadliwości dotychczasowej regulacji. Acta Sci. Pol. Architectura, 19 (3), 21-28. doi: 10.22630/ASPA.2020.19.3.24

89/106/EWG) jako realizacja obowiązku transpozycji tej dyrektywy do krajowego porządku prawnego. Unijne rozporządzenia stosowane są bezpośrednio, dlatego ich przepisów nie trzeba i nie należy powtarzać. Zakaz powtarzania przepisów jest jedną $\mathrm{z}$ podstawowych dyrektyw tworzenia uporzackowanego prawa. Zadaniem, jakie autorzy nowych przepisów muszą dzisiaj zrealizować, konkretyzując (uszczegóławiając) podstawowe wymagania, jest uwzględnienie zmian, jakie unijne rozporządzenie 305/2011 wprowadziło w treści tych wymagań względem wymagań sformułowanych w dyrektywie 89/106/EWG.

\section{Sprzeczności z normami zharmonizowanymi}

Warto przy okazji przypomnieć, że unijne rozporządzenie 305/2011 oddziałuje na krajowych prawodawców także poprzez ustanowienie zakazu wchodzenia w kolizję przepisów krajowych z normami zharmonizowanymi. Tamtejszy art. 17 ust. 5 nakazuje, aby wraz z końcem okresu koegzystencji tych norm pozbawiać ważności wszystkie sprzeczne $\mathrm{z}$ nimi przepisy krajowe. Za sprzeczność powinno się przy tym uznawać zarówno wymagania wobec wyrobów budowlanych (w tym elementów i systemów budowlanych będących wyrobami budowlanymi) odmienne od wymagań progowych zawartych $\mathrm{w}$ normach zharmonizowanych, jak i m.in. wykorzystywanie w przepisach klasyfikacji lub określeń technicznych innych niż wynikające $\mathrm{z}$ odpowiednich norm. Przepisy krajowe, w tym te dotyczące budynków i innych obiektów budowlanych, nie mogą bowiem producentom wyrobów budowlanych lub uczestnikom procesu budowlanego sugerować istnienia obowiązku określania dla danego wyrobu budowlanego objętego normą zharmonizowaną właściwości użytkowej dodatkowej cechy lub obowiązku określania właściwości użytkowej jakiejś normowej cechy zasadniczej przy użyciu metody innej niż wskazana w normie. Oceny niesprzeczności przepisów krajowych z normami zharmonizowanymi powinny być dokonywane za każdym razem, kiedy kolejna nowa lub znowelizowana norma była dodawana do wykazu odniesień publikowanego przez Komisję Europejską w Dzienniku Urzędowym UE. W przypadku rozporządzenia WT z 2002 r. takie analizy nie były przeprowadzane, dlatego muszą być uwzględnione podczas prac nad nowym rozporządzeniem.

\section{Powoływanie Polskich Norm}

Poruszenie tematu norm technicznych podczas omawiania przepisów rozporządzenia WT z 2002 r. nieuchronnie przekierowuje zainteresowanie $\mathrm{w}$ stronę problemu powoływania takich norm $\mathrm{w}$ krajowych przepisach prawa powszechnie obowiązującego. W przedmiotowym rozporządzeniu powołano około 150 unikatowych Polskich Nom, przy czym większość $\mathrm{z}$ nich powołana jest $\mathrm{w}$ sposób, który sugeruje nałożenie obowiązku ich stosowania. Powołanie w przepisach prawa Polskiej Normy (lub jakiegokolwiek innego dokumentu - w rozporządzeniu WT z 2002 r. powołany jest choćby dokument N SEP-E-004:2003, niebędący przecież Polską Normą) może mieć rozmaity charakter, nie każde wszak powołanie jest równoznaczne z nakazem stosowania. O skutkach powołania decyduje brzmienie przepisu (zwrotu) powołującego, a nie samo wymienienie normy w przepisie. Powołanie Polskiej Normy w przepisach prawa powszechnie obowiązującego, którego rezultatem miałoby być nałożenie skutecznego nakazu stosowania powołanej normy, aktualizuje obowiązek dochowania przez powołującego wymogów, jakie na prawodawcę (zarówno ustawodawcę, jak i prawodawców niższego rzędu) nakłada przede wszystkim Konstytucja RP. Chodzi tutaj głównie o wymóg ustanawiania przepisów o charakterze powszechnie obowiązującym wyłącznie w formie aktów normatywnych wymienionych w art. 87 Konstytucji RP oraz o wymóg odpowiedniego ogłaszania tych przepisów. Zgodnie $\mathrm{z}$ art. 88 ust. 1 Konstytucji RP ogłoszenie jest bezwzględnym warunkiem wejścia w życie przepisów mających obowiązywać powszechnie. Szczegółowe zasady i tryb ogłaszania aktów normatywnych określa ustawa $\mathrm{z}$ dnia 20 lipca $2000 \mathrm{r}$. o ogłaszaniu aktów normatywnych i niektórych innych aktów prawnych, przy czym inne ustawy także mogą zawierać regulacje w tym zakresie. Aktualnie ani ta ustawa, ani żadna inna nie wskazują Polskiego Komitetu Normalizacyjnego jako podmiotu odpowiedzialnego za samodzielne i odpłatne ogłaszanie aktów normatywnych zawierających przepisy powszechnie obowiązujące. Należy jednocześnie wyraźnie podkreślić, że przytaczany w dyskusjach argument istnienia $\mathrm{w}$ art. 5 ust. 4 ustawy z dnia 12 września 2002 r. o normalizacji podstawy prawnej dla możliwości kreowania nowych źródeł prawa mającego obowiązywać 
powszechnie i znoszącej wskazane wymogi konstytucyjne jest argumentem całkowicie błędnym, ponieważ zwykła ustawa nie może ustanawiać wyjątków od przepisów rangi konstytucyjnej. Polskie Normy powołane w rozporządzeniu WT z 2002 r. nie zostały ogłoszone zgodnie $\mathrm{z}$ obowiązującymi przepisami, a zatem nie weszły w życie i nie stanowią źródła wiążących wymagań technicznych stawianych budynkom. W wielu przypadkach oznacza to brak skutecznych wymagań w stosunku do bardzo istotnych elementów budynków (na przykład w stosunku do izolacyjności akustycznej przegród budowlanych).

\section{Wykraczanie poza upoważnienie}

Innym poważnym zarzutem stawianym rozporządzeniu WT z 2002 r. jest regulowanie w nim spraw wykraczających poza zakres upoważnienia zawartego w ustawie. Upoważnienie sformułowane w art. 7 ust. 2 ustawy Prawo budowlane nie przewiduje na przykład, że w rozporządzeniu wykonawczym określającym warunki techniczne, jakim powinny odpowiadać budynki i ich usytuowanie, formułowane będą przepisy modyfikujace ustawowy tryb odstepowania od tych warunków technicznych (w tym w sposób ignorujący ustawowe kryterium „szczególnego uzasadnienia”), tj. przepisy ingerujące $\mathrm{w}$ procedurę opisana $\mathrm{w}$ art. 9 ustawy Prawo budowlane (np. $\S 2$ ust. 2 i 3a, § 36 ust. 4, $\S 222$ ust. 2), albo przepisy uzależniające możliwość stosowania ustanowionych warunków technicznych od uzyskania czyjejś zgody (np. § 58 ust. $2, \S 72$ ust. 2 , $\S 132$ ust. $2, \S 184$ ust. 2). We wskazanym upoważnieniu nie przekazano prawodawcy wykonawczemu także kompetencji do ingerowania w zakres projektu budowlanego ustalony w art. 34 ustawy (np. § 36 ust. 6 , $\S 206, \S 322$ ust. 3). Takie regulacje rozporządzenia WT z 2002 r. nie mieszczą się w określeniu ,warunki techniczne" i dlatego nie mogą być przedmiotem przepisów wydawanych na podstawie art. 7 ustawy Prawo budowlane. Niewątpliwie wpływ na kształt i defekty rozporządzenia WT z 2002 r. miało rozporządzenie Ministra Gospodarki Przestrzennej i Budownictwa z dnia 14 grudnia 1994 r. w sprawie warunków technicznych, jakim powinny odpowiadać budynki i ich usytuowanie (zwane dalej rozporządzeniem WT z 1994 r.). Rozporządzenie WT z 2002 r. stanowi bowiem $\mathrm{w}$ dużej mierze powielenie rozporządzenia
WT z 1994 r., zrealizowane bez większej refleksji nad zmianami wymagań w zakresie tworzenia prawa, jakie przyniosło wejście w życie nowej konstytucji w 1997 r. Ignorowanie przez autorów rozporządzenia ram, jakie zostały dla tej regulacji ukształtowane ustawą, ma dalece szerszy zasięg i wyraża się również poprzez formułowanie niektórych przepisów w sposób, z którego wynika, że przepisy te znajdują zastosowanie także wtedy, kiedy nie mamy do czynienia $\mathrm{z}$ budynkiem. Przykładowo $\S 1$ oraz przepisy działu II sugerują, że w rozporządzeniu WT z 2002 r. stawiane sa wymagania wobec zagospodarowania samych działek budowlanych, tj. niezależnie od tego, czy na działce faktycznie sytuuje się budynek, czy nie. Tymczasem same działki budowlane, nawet te, dla których przeznaczenie pod zabudowę budynkami jest $\mathrm{w}$ danym momencie narzucone lub uzgodnione, pozostają poza zakresem przedmiotowym tego rozporządzenia, ponieważ ma ono - zgodnie z upoważnieniem ustawowym - określać wymagania wobec budynków, usytuowania tych budynków oraz wobec urządzeń budowlanych związanych (w znaczeniu funkcjonalnym) $\mathrm{z}$ tymi budynkami. A zatem Prawo budowlane dopuszcza formułowanie w rzeczonym rozporządzeniu wymagań wobec działek budowlanych wyłącznie wtedy, kiedy mają być konsekwencją sytuowania na tych działkach budynków. Należy też pamiętać, że jeżeli urządzenie budowlane, np. parking czy ogrodzenie, nie jest związane $z$ budynkiem, to wymagania zawarte w rozporządzeniu WT z 2002 r. nie znajdują wobec niego zastosowania.

\section{Przepisy odrębne}

Opracowanie nowych przepisów techniczno-budowlanych dla budynków, oprócz położenia większego nacisku na zapewnienie pełnej zgodności z ustawą Prawo budowlane, powinno być realizowane $\mathrm{z}$ uwzględnieniem bardziej starannej niż dotychczas analizy zgodności z przepisami także innych ustaw. Aktualne rozporządzenie wkracza w zakres spraw objętych wieloma różnymi ustawami; przyszłe relacje z niektórymi z nich wymagają szczególnie uważnego przemyślenia (choćby z ustawą z dnia 27 marca 2003 r. o planowaniu i zagospodarowaniu przestrzennym w kontekście swoistego asekurowania miejscowych planów zagospodarowania przestrzennego przepisami rozporządzenia 
WT z 2002 r.). W nowym rozporządzeniu nie można rzecz jasna kopiować tych przepisów rozporządzenia WT z 2002 r., które są wprost niezgodne z przepisami odrębnych ustaw (takim przepisem jest na przykład $\S 34$ ust. 1 , który jest niezgodny $\mathrm{z}$ art. 5 ust. 1 pkt 2 ustawy z dnia 13 września 1996 r. o utrzymaniu czystości i porządku w gminach oraz z art. 83 ust. 4 ustawy $\mathrm{z}$ dnia 20 lipca 2017 r. - Prawo wodne). W odniesieniu do „odrębności” przepisów (także tych niższego rzędu niż ustawowe) ważne jest ponadto, aby nie naśladować zabiegu uporczywego odsyłania do przepisów odrębnych określonych jedynie przedmiotowo (często takie odesłania stosowane są „na wszelki wypadek”, co można wręcz nazwać odesłaniami do „ewentualnych" przepisów odrębnych). Spośród takich odesłań sformułowanych w rozporządzeniu WT z 2002 r. można dodatkowo wyodrębnić dość osobliwe przepisy, z których wynika, że stosowanie przepisów odrębnych zawartych w innych aktach normatywnych jest nakazywane (m.in. $\S 44, \S 45, \S 77$ ust. $1, \S 193$ ust. 4, $\S 208$ ust. 2 pkt 1), przy czym nie sa to odesłania do odpowiedniego stosowania wskazanych przepisów. Obowiązywanie innych aktów normatywnych oraz obowiązek ich stosowania nie jest rezultatem nakazów zamieszczanych w rozporządzeniu WT z 2002 r., są one więc całkowicie zbędne. Te osobliwe przepisy pozostają zbędne, nawet jeżeli miałyby być uznawane za potwierdzenie obowiązku równoległego stosowania przepisów odrębnych zawartych w innych aktach normatywnych (tj. za potwierdzenie nienaruszania ich). Potrzeby takiego potwierdzania nie ma, ponieważ rozporządzeniem nie można znosić lub ograniczać stosowania ani przepisów ustaw, ani przepisów innych rozporządzeń, a zatem nie ma podstaw do zaistnienia w tym zakresie wątpliwości interpretacyjnych. Nakazy/potwierdzenia tego typu nie pełnią też funkcji informacyjnej, bo o takiej można byłoby mówić w przypadku odesłań precyzyjnych, tj. wskazujących tytuły i adresy publikacyjne aktów, do których następuje odesłanie (wówczas przynajmniej byłyby dla adresatów przepisów rzeczywistą wskazówką, gdzie powinni szukać innych wymagań, które również odnoszą się do materii uregulowanej w danym przepisie techniczno-budowlanym). Co więcej, wybiórczość w lokalizowaniu w rozporządzeniu WT z 2002 r. takich nakazów może wprowadzać w błąd, ponieważ sugeruje, że zewnętrzne przepisy odrębne istnieją jedynie w odniesieniu do tych przepisów technicznobudowlanych, przy których zamieszczono opisane odesłanie. Te zaś w systemie prawa mogą istnieć zupełnie niezależnie, a skoro zazwyczaj nie można wykluczyć, że istnieją albo że zostaną w przyszłości wydane, to zastrzeżenie, że należy stosować przepisy odrębne, mogłoby znaleźć się przy dosłownie każdym przepisie rozporządzenia WT z 2002 r. i przy żadnym nie wnosiłoby nowości normatywnej.

\section{Błędy legislacyjne}

Powyższe spostrzeżenia mogłyby stanowić wstęp do dalszych, bardzo szczegółowych uwag dotyczących legislacyjnej warstwy rozporządzenia WT z 2002 r. Akt ten niestety obfituje w błędy odbierające jego przepisom przymiot komunikatywności i wytrwale lekceważy dyrektywy konstruowania przepisów prawa spisane w rozporządzeniu Prezesa Rady Ministrów z dnia 20 czerwca 2002 r. w sprawie „Zasad techniki prawodawczej". Zestawienie i analiza tych błędów wielokrotnie przekraczałyby objętość samego rozporządzenia. Część z nich została już krótko scharakteryzowana w niniejszym artykule, a inne najpowszechniejsze to choćby niekonsekwencje terminologiczne, błędne konstrukcje definicji, odesłania kaskadowe czy błędy interpunkcyjne. Błędy te są przyczyną poważnych problemów interpretacyjnych zarówno dla pierwotnych adresatów przepisów, jak i dla organów wydających rozstrzygnięcia administracyjne. Na analizy wadliwych przepisów marnowane są ogromne nakłady czasu, a rezultaty analiz bywają skrajnie różne nawet w bardzo porównywalnych stanach faktycznych.

\section{Warunki odstępstw}

Dodatkowo warto wspomnieć, że wśród materiałów wymagających rozważenia $\mathrm{w}$ trakcie prac nad nowym rozporządzeniem powinny znaleźć się również stanowiska ministra w sprawach upoważnień do udzielania zgód na odstępstwa od dotychczasowych przepisów. Należy przeanalizować możliwość formułowania przepisów zbieżnych z powtarzającymi się warunkami zamiennymi akceptowanymi w tych stanowiskach. Jeżeli w odniesieniu do danego przepisu upoważnienia udzielane są pod podobnymi warunkami, to uwzględnienie takiej alternatywy w samym przepisie 
Kułaga, K. (2020). Perspektywa nowych przepisów techniczno-budowlanych dotyczących budynków w świetle wadliwości dotychczasowej regulacji. Acta Sci. Pol. Architectura, 19 (3), 21-28. doi: 10.22630/ASPA.2020.19.3.24

spowoduje spadek liczby wniosków o zgodę na odstępstwo i dla wielu inwestorów skrócenie czasu oczekiwania na decyzję o pozwoleniu na budowę.

\section{PODSUMOWANIE}

Rozporządzenie WT z 2002 r. jest bardzo obszernym i skomplikowanym przedmiotowo aktem normatywnym. Kolejne nowelizacje powodowały pogłębianie jego pierwotnych wad, poszerzały wewnętrzną niespójność oraz dostarczały dodatkowych wątpliwości interpretacyjnych. Przyjąwszy, że nie sposób projektować nowe przepisy bez dokonania rzetelnej analizy aktualnych unormowań, należy ocenić, że zakres niezbędnej do wykonania pracy - również w świetle przeprowadzonego $\mathrm{w}$ niniejszym artykule przegląu - jest ogromny. Biorąc jednak pod uwagę nieprofesjonalność organizacyjna oraz dotychczasowe rezultaty działań prawodawcy odpowiedzialnego za przepisy techniczno-budowlane dotyczące budynków, prawdopodobieństwo, że w 2022 r. nastąpi istotna jakościowa zmiana tych przepisów, pozostaje niewielkie.

\section{PIŚMIENNICTWO}

Dyrektywa Rady nr 89/106/EWG z dnia 21 grudnia 1988 r. w sprawie zbliżenia przepisów ustawowych, wykonawczych i administracyjnych państw członkowskich odnoszących się do wyrobów budowlanych. Dz.Urz. UE L 40/12 z 11.02.1989, z późn. zm.

Konstytucja Rzeczypospolitej Polskiej z dnia 2 kwietnia 1997 r. Dz.U. 1997, poz. 483 z późn. zm.

Rozporządzenie Ministra Gospodarki Przestrzennej i Budownictwa z dnia 14 grudnia 1994 r. w sprawie warunków technicznych, jakim powinny odpowiadać budynki i ich usytuowanie. Dz.U. 1999 nr 15, poz. 140, z późn. zm.

Rozporządzenie Ministra Infrastruktury z dnia 12 kwietnia 2002 r. w sprawie warunków technicznych, jakim powinny odpowiadać budynki i ich usytuowanie. Dz.U. 2019, poz. 1065 .
Rozporządzenie Ministra Transportu, Budownictwa i Gospodarki Morskiej z dnia 25 kwietnia 2012 r. w sprawie szczegółowego zakresu i formy projektu budowlanego. Dz.U. 2012, poz. 462 z późn. zm.

Rozporządzenie Ministra Transportu, Budownictwa i Gospodarki Morskiej z dnia 25 kwietnia 2012 r. w sprawie ustalania geotechnicznych warunków posadawiania obiektów budowlanych. Dz.U. 2012, poz. 463.

Rozporządzenie Parlamentu Europejskiego i Rady (UE) nr 305/2011 z dnia 9 marca 2011 r. ustanawiającego zharmonizowane warunki wprowadzania do obrotu wyrobów budowlanych i uchylającego dyrektywę Rady 89/106/EWG. Dz.Urz. UE L 88/5 z 04.04.2011.

Rozporządzenie Prezesa Rady Ministrów z dnia 20 czerwca 2002 r. w sprawie „Zasad techniki prawodawczej”. Dz.U. 2016, poz. 283.

Ustawa z dnia 7 lipca 1994 r. - Prawo budowlane. Dz.U. 1994, poz. 414 z późn. zm.

Ustawa z dnia 13 września 1996 r. o utrzymaniu czystości i porządku w gminach. Dz.U. 2019, poz. 2010 z późn. zm.

Ustawa z dnia 20 lipca 2000 r. o ogłaszaniu aktów normatywnych i niektórych innych aktów prawnych. Dz.U. 2019, poz. 1461.

Ustawa z dnia 12 września 2002 r. o normalizacji. Dz.U. 2015, poz. 1483.

Ustawa z dnia 27 marca 2003 r. o planowaniu i zagospodarowaniu przestrzennym. Dz.U. 2020, poz. 293.

Ustawa z dnia 25 czerwca 2015 r. o zmianie ustawy o wyrobach budowlanych, ustawy - Prawo budowlane oraz ustawy o zmianie ustawy o wyrobach budowlanych oraz ustawy o systemie oceny zgodności. Dz.U. 2015, poz. 1165.

Ustawa z dnia 20 lipca 2017 r. - Prawo wodne. Dz.U. 2020, poz. 310 .

Ustawa z dnia 5 lipca 2018 r. o ułatwieniach w przygotowaniu i realizacji inwestycji mieszkaniowych oraz inwestycji towarzyszących. Dz.U. 2018, poz. 1496.

Ustawa z dnia 19 lipca 2019 r. o zapewnianiu dostępności osobom ze szczególnymi potrzebami. Dz.U. 2019, poz. 1696.

Ustawa z dnia 13 lutego 2020 r. o zmianie ustawy - Prawo budowlane oraz niektórych innych ustaw. Dz.U. 2020, poz. 471.

Wyrok Trybunału Konstytucyjnego z dnia 14 lutego 2006 r. sygn. akt P 22/05. Dz.U. 2006, poz. 215. 


\section{PERSPECTIVE OF NEW TECHNICAL PROVISIONS FOR BUILDINGS IN THE CONTEXT OF DEFECTS OF CURRENT REGULATION}

\section{ABSTRACT}

The article portrays the circumstances of the obligation to issue new technical provisions and, based on the example of the current Regulation on the technical conditions to be met by buildings and their location, it presents selected defects of this regulation and certain tasks facing the lawmaker who is to design a new regulation. The general negative assessment of the quality of the existing provisions, which is mainly influenced by legislative weaknesses, was reasoned.

Key words: technical conditions, buildings, new provisions, legislative technique 